\title{
Spanish Adaptation of the Stepparent Role Strain Index
}

\author{
Isabel Espinar Fellmann¹, María José Carrasco Galán ${ }^{1}$, \\ Isabel Muñoz San Roque ${ }^{1}$, and Inés Carrasco Galán² \\ ${ }^{1}$ Universidad Pontificia Comillas, Madrid \\ ${ }^{2}$ Universidad Complutense de Madrid
}

\begin{abstract}
Stepparent role strain refers to the fragile position of these family members in stepfamilies due to the lack of clear social expectations about their roles. This ambiguity facilitates family conflict and a lack of stepparents' integration into the family system. The aim of this paper is to adapt a pioneer measure of stepparent role strain-the Stepparent Role Strain Index of Whitsett and Land (1992) - in a Spanish sample and to analyze its construct validity. The final instrument is made up of 26 items which have good internal consistency $(\alpha=.89)$ and an underlying six-factor structure, explaining $64.50 \%$ of the total variance. Keywords: role strain, stepfamilies, stepfather, stepmother, factorial structure, construct validity
\end{abstract}

\begin{abstract}
La tensión de rol de los padrastros y de las madrastras alude a la frágil posición de estos miembros en las familias reconstituidas, debido a la ausencia de expectativas sociales sobre su rol, facilitando la aparición de discrepancias familiares así como la inadecuada integración del padrastro y de la madrastra en el sistema familiar. El objetivo de este trabajo es adaptar a una muestra española un instrumento pionero en la medida de la tensión de rol de los padrastros y de las madrastras, el Índice de Tensión de Rol de Whitsett y Land (1992). El instrumento queda formado por 26 ítems que obtienen una óptima consistencia interna $(\alpha=.89)$. La estructura factorial muestra 6 factores que explican el $64.50 \%$ de la varianza total.

Palabras clave: tensión de rol, familias reconstituidas, padrastros y madrastras, estructura factorial, validez de constructo
\end{abstract}

Correspondence concerning this article should be addressed to: Isabel Espinar Fellmann, Universidad Pontificia Comillas, Facultad de Ciencias Humanas y Sociales, C/ Comillas, 3, Campus de Cantoblanco , 28049, Madrid (Spain). Phone: 91- 734-3950 E-mail: iespinar@chs.upcomillas.es

Translation: Virginia Navascués Howard. 
The predominant type of family that in most western societies, not only in frequency but also in acceptance, is the nuclear or intact family, that is, a family made up of a man and a woman legally joined by the institution of matrimony who, along with their decadence, share a common home. However, new modalities of family organization, which will become more widespread in the not-so-far future, have begun to emerge. The progressive increase of separation and divorce rates has favored the appearance of single-parent families, generally headed by a woman, although the duration of this kind of families is sometimes time-limited, as reflected by the rates of second nuptials or cohabitation of separated or divorced people. Second nuptials or living with a new partner can, in turn, lead to the establishment of another family modality, reconstructed families, which are defined as family structures in which one or both members of the couple have had at least one child from a previous relation (Gorell-Barnes, Thompson, \& Burchardt, 1997).

The studies that provide current sociodemographic data about the rates of second marriages have been mainly carried out with North American population. In the USA, the nuclear family has ceased to be the prototypical family structure, as about $60 \%$ of first marriages end in divorce (Bumpass, Martin, \& Sweet, 1991), and most divorcees remarry. In 1994 alone, 50\% of the marriages were second marriages (National Center for Health Statistics, 1994). One out of every six families is a reconstructed family, which represents $17 \%$ of all family forms (Glick, 1989; Orleans, Palisi, \& Caddell, 1989), and the USA is the country with the highest percentage of second marriages. The forecasts for the next decades point in the same direction, indicating that reconstructed families will be the most common family structure in the $21^{\text {st }}$ century (Bernstein, 2000).

Although marital disruptions in Spain have not reached the same levels as in Europe and the USA, an increase in the divorce rates has been observed since the enforcement of the divorce law in 1981 (Menéndez, 2001). Whereas the separation rate in 1982 was $9.02 \%$, and the divorce rate was $11.10 \%$, in the year 2000 , the rate of separations rose to $32.28 \%$ and the divorce rate to $20.03 \%$ (Campo \& Rodríguez-Brioso, 2002). Separations and divorces are also accompanied by an increase in the number of couples who, by means of new marriages or cohabitation, establish reconstructed families (Alberdi, 1999; Flaquer, 1999; Iglesias de Ussel, 1994, 1998). The "Anuario Estadístico del Instituto Nacional de Estadística" (in English, the Statistical Annuary of the National Statistics Institute; I.N.E., 2001) shows that, whereas in 1993, 5.03 and $3.82 \%$, respectively, of the separated or divorced men and women remarried, in the year 2000 , these rates increased to $5.73 \%$ for men and $4.90 \%$ for women.

With regard to the stability of remarried couples, various studies coincide that they are more unstable than first- marriage couples. Whereas some authors note that almost one half of the remarried couples separate in less than 5 years (McGoldrick \& Carter, 1999), others observe that this dissolution occurs during the first 2 years of the relation (Lawton \& Sanders, 1994).

From the theory of roles, a family can be conceived as a status system in which each member occupies one or various positions that will determine that member's rights, obligations, and responsibilities towards the other members, who occupy other family positions, and which, will ultimately define the family roles. Stepparents' position in the reconstructed family involves some difficulties that the literature has reflected under the term of role strain or stress. Some authors have defined this construct as the difficulties perceived by people when they attempt to fulfill the demands, expectations, or obligations associated with a role (Goode, 1960; Pearlin, 1983).

The absence of legal rights and obligations in some family relations that include a stepparent contributes to the lack of clearly prescribed rules about the stepparent's position in the family setting. This situation obliges each family system to negotiate the way this new family member should fit in and in which family settings or areas. However, the various members' diverse expectations about the stepparent's role is a source of discrepancy and conflict. Various authors have indicated how such differences, particularly with regard to stepparents' involvement in the education and bringing up of their stepchildren, is an important source of family stress (Ihinger-Tallman \& Pasley, 1987; Visher \& Visher, 1983)

The social myths and stereotypes about the members of reconstructed families have not made the definition of family roles any easier. Stereotypes about stepparents describe them as being reserved, cruel individuals, who are unconcerned about their stepchildren, whereas stepchildren are usually portrayed as being abandoned, unattended, and deprived of parental love and affection (Ganong \& Coleman, 1983). Although the literature has perpetuated a particularly negative view of stepmothers, neither have stepfathers been able to avoid such pejorative connotations. Some myths have made a particularly hard impact on stepmothers, making them more susceptible to experience higher levels of stress than do stepfathers (Fine \& Schwebel, 1991). The well-known myth of the evil stepmother probably originated in the maternity myth that has propitiated the current idealization of maternity and the widespread social view of the woman and mother as mainly responsible for the stability and quality of family life, the person most able to guarantee her children's development and well-being. This phenomenon has led to the co-existence of two clearly incompatible myths about stepmothers. On the one hand, just because she is a woman, she is expected to develop certain affectionate feelings and behaviors towards her stepchildren when, to start with, her projected image is that of a cruel and perverse individual. 
Stepparents have been considered key pieces in the good functioning of reconstructed families; in fact, their integration in the family system has been mentioned as one of the main tasks that all reconstructed families should undertake (Bray, Berger, \& Boethel, 1994). However, the difficulties commonly experienced by these members when performing their family roles could hinder their integration into the family circle and lead to family dissolution.

Various works have focused on studying how the family can behave so that stepparents can define their position or role in the family system. However, many of the orientations or suggestions derive from therapeutic work with problematic or dysfunctional reconstructed families, and there are few empirical studies that have used standardized measures to assess the quality of stepparents' role performance in nonclinical reconstructed families. Thus, although some works underscore the incidence of role strain in reconstructed families with some degree of dysfunction, whether or not this variable is more or less generalized in nonclinical reconstructed families and whether it has negative consequences on stepparents' health has not yet been studied

The first empirical contribution to the study of stepparent role strain and its measure was by Whitsett and Land (1992) who, from the theoretical framework of Pearlin (1983), defined and delimited the concept and elaborated an assessment instrument. According to these authors, the concept of role strain is especially relevant in the population of stepparents as it reflects the difficulties they commonly express when undertaking diverse family roles. Stepparent role strain comprises the following dimensions: change of roles, ambiguous family limits, role inclusion and exclusion, role ambiguity, role conflict, and role congruence. Forming a reconstructed family implies, first of all, some changes and readjustments in role performance, with the gain and/or loss of roles of the members who comprise the family becoming a possible source of stress. The clearest case frequently occurs when the stepparent is obliged to assume a parental role almost simultaneously with the marital role. Ambiguous family limits, the result of the presence of family members from different homes, is usually reflected in the lack of agreement among some of the reconstructed family members about who belongs to the family structure. The existence of two family circles, joined by legal obligations and rights and emotional links, forces the marital subsystem to constantly tighten or loosen its limits to meet the diverse needs of the members, and this may trigger stress in the stepparent. Role inclusion and exclusion refers to the fact that, due to the presence of other family figures in other circles (children, fathers and/or mothers), the stepparents may feel excluded from some relations or from family decision making, or included in some issues in which they would prefer not to take part. Whereas investigations have shown that well-defined and clear expectations about roles lead to better performance, stepparents usually have serious difficulties delimiting their role in the reconstructed family, generally revealing role ambiguity, that is, feeling uncertain about how they should behave. Role conflict refers to the incompatibility between the performance of two or more roles that a person carries out or should carry out. Whereas inter-role conflicts emerge as a result of contradictory expectations between two or more roles occupied at the same time, intra-role conflicts refer to the contradictory expectations that different people have about the role carried out by an individual, and both types of conflict are frequently associated with the figure of the stepparent. Intra-role conflicts may be the most frequent in reconstructed families because of the lack of agreement among the different family members regarding what is considered suitable or unsuitable about the stepparent's performance. Role captivity, an intrarole conflict modality, appears when the stepparent is obliged to carry out an unwanted role. This situation can originate because the stepparent's partner wants him or her to assume more responsibility in the education of the stepchildren. Role congruence is the degree to which people perceive that their beliefs, values, and desires match the demands of a certain role. Many stepparents do not always behave as they would like to, or else they try to hide some of their feelings, and this may be related to their dissatisfaction with their role performance.

According to these dimensions, Whitsett and Land (1992) designed the Stepparents Role Strain Index, elaborating 51 items and administering it to a North American sample of 73 stepparents ( 32 stepfathers and 40 stepmothers). The rating scale ranged between 1 and 5, with higher scores indicating higher levels of role strain. After factor analysis, a 30-item version was selected, which had an adequate reliability index (Cronbach's $\alpha=.91$ ), and eight underlying factors with an alpha ranging between .60 and .94 .

The items that comprised Factor 1 (5 items, $\alpha=.87$ ), named Role Ambiguity, show the degree to which stepparents know their partner's' expectations about their behavior towards the stepchild/stepchildren in typically parental tasks. Role Conflict (Factor 2, 3 items, $\alpha=.76$ ) assesses the degree of interference between professional and family role performance. The dimension called Role Captivity (Factor 3, 3 items, $\alpha=.74$ ) reflects stepparents' dissatisfaction with the role because others' needs are being prioritized. The items that comprise Role Incongruence (Factor 4, 5 items, $\alpha=.94$ ) reflect a situation in which the stepparents' manifest feelings and behaviors do not match their true feelings toward their stepchild. Feelings of Inclusion/Exclusion (Factor 5, 3 items, $\alpha=.71$ ) assesses stepparents' dissatisfaction with their position in the family system. The dimension Ambiguous Family Limits (Factor 6,5 items, $\alpha=.79$ ) reflects the stepparent's relation with and appraisal of the various original family members, especially of the partner's ex-spouse. Partner's Emotional Support (Factor 7, 3 items, $\alpha=.70$ ) refers to the support provided by the stepparent's partner when the stepparent is performing his or her role within the family system. And, 
lastly, the dimension called Resources (Factor 8, 3 items, $\alpha$ $=.60)$ refers to certain aspects involving the regulation of family life together.

The purpose of this work is to adapt Whitsett and Land's (1992) Stepparent Role Strain Index to a Spanish sample of stepparents. To confirm the relation of this measure with a complementary instrument, we chose the Step-Parent Role Clarity Inventory (SRCI; Fine, Coleman, \& Ganong, 1998), which is made up of 8 items that assess the degree of stepparents' certainty and confidence about their behavior concerning their stepchildren's upbringing and education. Stepparents rate, on a 7-point Likert-scale, their degree of agreement or disagreement with the 8 statements. Total scores range between 8 and 56, with higher scores indicating higher levels of role clarity. In a sample of 40 stepparents, the authors found a reliability of Cronbach's $\alpha=.82$. We chose this instrument because the items reflect an aspect of role performance - role clarity - that the literature has defined as particularly problematic in reconstructed families. Stepparents' parental role towards their stepchildren is commonly a source of stress for many reconstructed families. The instrument of Fine et al. focuses exclusively on stepparents' perception of their parental role, using a stepparents' role performance matrix that is not included in the instrument elaborated by Whitsett and Land.

\section{Method}

\section{Participants}

In this study, 116 stepparents participated (49 stepfathers and 67 stepmothers). The mean age of the sample was 44.26 years $(S D=7.90)$; the stepfathers' mean age was 47.39 years $(S D=8.45)$, and the stepmothers' 41.97 years $(S D=6.66)$. The total sample had been living on average almost 8 years with their current partner $(M=7.97$ years, $S D=5.19)$; the stepfathers' mean duration of living together was 7.20 years $(S D=4.85)$, and the stepmothers' was 8.52 years $(S D=$ 5.40 ). With regard to family structure, $46.56 \%$ of the individuals made up simple reconstructed families (only one member of the couple had a child or children from a previous relation) and $53.44 \%$ comprised complex reconstructed families (both members of the couple had a child or children from a previous relation). Most of the stepfathers $(65.30 \%)$ lived in complex reconstructed families and most of the stepmothers $(55.22 \%)$ in simple reconstructed families.

Most of the stepfathers (90.63\%) lived temporarily with their own children and permanently (75\%) with their stepchildren, whose mean age was 15.79 years. Most of the stepmothers $(70 \%)$ lived permanently with their biological children and temporarily $(78.46 \%)$ with their stepchildren, whose mean age was 20.93 years. The group of stepfathers had between 1 and 5 stepchildren and the stepmothers had between 1 and 9 stepchildren. However, most stepparents had either 1 (38.77 and 40.29\%, respectively, for stepfathers and stepmothers) or 2 stepchildren (51.02 and $41.79 \%$, for stepfathers and stepmothers, respectively). The majority (79.59 and $65.67 \%$, respectively, for stepfathers and stepmothers) had not had children in their current relation. Regarding educational level, $56.88 \%$ of the total sample had university studies, in contrast to $42.23 \%$, who had primary and/or secondary studies. Whereas a higher percentage of the stepmothers had a university degree (46.26\%), in the stepfathers, the percentage of those with secondary studies and those with a university degree was the same $(32.65 \%)$. Lastly, with regard to economic level, both the stepfathers and the stepmothers stated that they earned an income (among both couple members) of over 3000/month (32.65 and $44.77 \%$, for stepfathers and stepmothers, respectively). Statistical analyses revealed statistically significant differences in the following variables: stepfathers' agetheir mean age was higher than that of the stepmothers, $t(88)$ $=3.71, p=.00$; type of family structure-most of the stepfathers lived in complex reconstructed families, whereas in the stepmothers, simple reconstructed families predominated, $\chi^{2}(1, N=116)=4.79, p=.02$; and the time the stepparents had lived with their biological children, $\chi^{2}(1$, $N=58)=30.14, p=.00$, and with their stepchildren, $\chi^{2}(1$, $N=103)=48.83, p=.00$.

To sum up, the participants in this study are characterized by having a mean age of 44 years, comprising fairly stable reconstructed families, as they have been living together on average for almost 8 years. Family structure is relatively balanced although complex reconstructed families tend to predominate slightly. As various studies indicate, fathers and stepfathers tend to live temporarily with their own children and permanently with their stepchildren, and mothers and stepmothers usually live permanently with their own children and temporarily with their stepchildren. Most of the participants have not had children in the current relationship. The participants had high educational and economic levels.

\section{Procedure}

So as not to change the meaning and nuances of the items used by the original authors, we made a simple translation (without any changes or adaptations) of their items. However, it is noted that this kind of translation does not guarantee content validity. Once the instrument had been refined, a group of three expert judges in the area of family relations, who were quite familiar with the theoretical model, analyzed the content of these items and confirmed their suitability to measure the variable role strain.

The participants in this study were obtained mainly by the snowball technique. Various groups (associations of separated and divorced people, university students, professors) were contacted and requested to send the 
questionnaire and a stamped envelope with our complete address to the stepparents so they could return the completed questionnaire. Despite the fact that we sent a considerable number of questionnaires, as most people knew some stepfather or stepmother, only 121 questionnaires were returned, from which we had to eliminate 5 because of missing values in some items or because the respondents were not really stepparents (this was confirmed from the sociodemographic data provided). Thus, the statistical analyses were carried out with 116 participants.

\section{Results}

\section{Reliability}

The Spanish version of the Stepparent Role Strain Index obtained a good degree of internal consistency (Cronbach's $\alpha=.89$ ). Likewise, each of the six factors obtained showed acceptable reliability: Factor 1: $\alpha=.91$, Factor $2: \alpha=.82$, Factor 3: $\alpha=.77$, Factor 4: $\alpha=.81$, Factor 5: $\alpha=.73$, Factor 6: $\alpha=.58$ ).

\section{Instrument Dimensionality}

After the Kaiser-Meyer-Olkin measure of sample adequacy had been analyzed $(K M O=.80)$ and Barlett's sphericity test, which indicates adequate use of multivariate analysis, had been applied, $(\chi=1761.72, p<.001)$, we performed factor analysis on the initial version of the instrument. The Spanish version of the Stepparent Role Strain Index is comprised of 26 items, 4 less than the original instrument of Whitsett and Land (1992). We used the following criteria to obtain the final factor solution: (a) we eliminated from the Varimax rotated component matrix the factors that did not have enough items (less than 3, according to the criterion of Kim \& Mueller, 1994). This decision was also based on the fact that the content of the eliminated items was already reflected in other items on other factors. As a result, Items 2, 8, and 10 were eliminated. (b) We also eliminated Item 5 because it lacked clear conceptual coherence that would allow us to place it on the two factors where its factor loading was highest.

In the final version (after eliminating these 4 items), factor analysis (unrotated matrix, principal components method) yielded 6 factors that accounted for $64.50 \%$ of the total variance. The first factor accounted for $28.78 \%$ of the total variance (quite far from the variance accounted for by the second factor: $11.69 \%$ ) and most of the items loaded highest on this first factor.

In Table 1 are displayed the 6 factors, grouping between 4 and 5 items with high loadings on the rotated matrix (Varimax method). The sets of items belonging to each of the 6 factors generally have a common and clear interpretation. The index of fit of factor scales (IFFS;
Fleming, 1985) expresses the proportion of variance accounted for by the items selected to define each factor in relation to all the items. The minimum value should be somewhat higher than .50 , a value of .60 is acceptable, and a value of around .70 indicates a good selection of the items that represent the factor. The IFFS values obtained were optimum for Factors 1, 4, and 6 (obtaining values between .72 and .87), and acceptable for Factors 2, 3, and 5 (reaching values between .60 and .66).

The items that make up Factor 1 correspond to the same factor found by Whitsett and Land (1992), which they called Role Ambiguity and which we called Ambiguity in Parental Role Expectations. Factor 2 includes 4 items that reflect the stepparent's feeling worn out or overloaded due to having to perform different roles or to give priority to the demands or needs of other individuals. Rather than a situation in which the stepparents' diverse roles are incompatible, they reflect the stepparents' difficulty to attend or perform the roles. Therefore, we called this factor Role Overload. Factor 3 is made up of 5 items that appraise stepparents' distress when competing with the partner's relationship with his or her children. This distress can be due to their experience of exclusion or loss, so we called this factor Displacement in the Paternal-Filial Subsystem. The 4 items than make up Factor 4 clearly describe a mismatch between the relation that the stepparent would like to have with his or her stepchildren and the real relation. The statements refer both to the discrepant feelings or affect towards the stepchildren and those the stepparent would prefer or believes he or she should feel, as well as the distribution of time and material objects the stepparents would like to share or believe they should share with their stepchildren. This factor was named Affective Ambivalence. Factor 5 was called Normative Discordance; it is made up 4 items that reflect situations involving the distribution of the family system's resources, such as economic resources or power in decision making. Factor 6 includes 4 items that refer exclusively to the possible interference of the ex-spouse in the family relations of the stepparents and that could affect both the couple relation and the relation with their stepchildren, so this factor was named Ex-Spouse's Interference.

In Table 2 are displayed the correlations obtained between the Spanish version of the Stepparent Role Strain Index and the 6 factors that comprise it. Most of the correlations among the diverse factors were statistically significant. The highest correlations were obtained between Factor 2 (Role Overload) and 5 (Normative Discordance), $r=.55, p=.01$, and between Factor 3 (Displacement in the Paternal-Filial Subsystem) and Factor 5 (Normative Discordance), $r=.55, p=.01$. These data indicate that the higher the stepparents' overload, and the worse they appraise their position concerning their partner's relation with his or her children, the more difficulties they will have in issues involving the distribution of family resources. The correlations of Factor 3 (Displacement in the Paternal-Filial 
Table 1

Facture Structure of the Spanish Version of the Stepparent Role Strain Index

Items Factor and Item wording

Factor loading

(rotated matrix)

FACTOR 1. Ambiguity in Parental Role Expectations

1 Sé perfectamente lo que mi pareja espera de mí con respecto a su/s hijo/s en los siguientes aspectos:

1.1 Disciplina

1.2 Tareas escolares

1.3 Tareas cotidianas

1.4 Crianza

1.5 Tiempo que pasamos juntos $\quad .726$

$\begin{array}{lr}\text { Eigenvalue } & 4.05\end{array}$

\% Variance accounted for 15.60

FACTOR 2. Role Overload

7 A veces desearía poder escapar de las múltiples demandas que debo satisfacer.

13 El régimen de visitas me resulta costoso pues me obliga a adaptarme a las necesidades de otros.

14 Siento como si continuamente tuviera que ajustar mis diferentes funciones (como esposo/a, profesional, como padre/madre...) para responder a las demandas de cada uno de ellos.

15 A veces siento que no estoy atendiendo lo suficiente a mis propias necesidades en un intento de cubrir las de los demás.

Eigenvalue

$\%$ Variance accounted for

FACTOR 3. Displacement in the Paternal-Filial Subsystem

4 A veces me siento excluido de la relación entre mi pareja y su/s hijo/s.

6 Creo que mi papel como padrastro/madrastra sería más fácil si mi pareja me ayudara más.

24 Creo que mi papel como padrastro/madrastra sería más fácil si mi pareja me apoyara más en cuestiones de disciplina con su/s hijo/s.

25 Me fastidia tener que compartir el tiempo que disponemos como pareja con su/s hijo/s.

26 Cuando pienso en mis experiencias como padrastro/madrastra, en general, me siento enfadado/a.

$\%$ Variance accounted for

\section{FACTOR 4. Affective Ambivalence}

16 Ojalá sintiera hacia el/los hijo/s de mi pareja lo que creo que debería sentir.

18 Ojalá desease pasar más tiempo con el/los hijo/s de mi pareja.

20 Ojalá desease compartir más mis cosas con el/los hijo/s de mi pareja.

22 Me gustaría tener sentimientos más positivos hacia el/los hijo/s de mi pareja.

$\%$ Variance accounted for

FACTOR 5. Normative Discordance

3 A pesar de todos nuestros esfuerzos nunca tenemos suficiente dinero para cubrir nuestras necesidades.

11 Los acuerdos de convivencia no son adecuados para cubrir nuestras necesidades familiares.

12 Me gustaría que se contara más conmigo en lo que respecta a la toma de decisiones familiares.

21 Desearía poder apoyarme más en mi pareja.

$\%$ Variance accounted for

FACTOR 6. Ex-Spouse's Interference

9 Me gustaría que mi pareja me comentase con más frecuencia lo que siente hacia su ex-cónyuge.

17 Creo que el ex-cónyuge de mi pareja interfiere en nuestra relación.

19 Creo que el/los hijo/s de mi pareja sienten que tienen que escoger entre su padre/madre biológico y yo.

23 Creo que el ex-cónyuge de mi pareja interfiere en la relación que mantengo con su/s hijo/s. 
Subsystem) with Factor I (Role Ambiguity) and with Factor 2 (Role Overload) are also moderate, $r=.52$ and $r=.50$, respectively, $p=.01$, indicating a high relation between stepparents' feeling of mismatch in their partner's relation with his or her children and their experience of role ambiguity and role overload. All the statistically significant correlations at the $p<.01$ level were also significant using the Bonferroni adjustment $(p<.002)$.

\section{Divergent Validity}

In Table 3, it can be seen that the correlation between the Stepparent Role Strain Index and the SRCI (Fine et al., 1998) is inverse and statistically significant. This is reasonable and suggests that the higher the level of strain experienced by stepparents in the family circle, the lower their degree of clarity and confidence about their role with their stepchildren.

The correlations among the diverse factors that comprise the Stepparent Role Strain Index and the SRCI (Fine et al., 1998) are also shown in Table 3. All the statistically significant correlations at the $p<.001$ level were also significant using the Bonferroni adjustment ( $p$ $<.002)$. The SRCI obtained inverse and statistically significant correlations with Factors 1, 2, 3, 4, and 5. That is, the more clearly defined the stepparents' parental role in the family system, the lower their lack of knowledge of their partner's expectations about their behavior in issues of discipline, school work, daily tasks, childcare, and shared time. Likewise, the higher their role clarity, the lower their affective ambivalence towards their stepchildren and the less perceived distress due to their position in their partner's relation with his or her child. Lastly, the higher their role clarity, the lower the discordance caused by regulating family life together (matching resources and needs, decision making, etc.). Although statistically significant, the correlation between the SRCI and role overload was lower, indicating a lower relation between stepparents' confidence in their parental role and their feeling of mismatch when trying to make their diverse roles compatible. Lastly, the degree of stepparents' confidence in their parental behavior was not associated with their appraisal of the intromission of their partner's ex-spouse in their current relationship.

\section{Discussion and Conclusions}

The goal of this work was to adapt a pioneer instrument in the measure of stepparents' role strain-the Stepparent Role Strain Index of Whitsett and Land (1992)_to a Spanish sample.

Table 2

Correlations Matrix among the Stepparent Role Strain Index Factors

\begin{tabular}{|c|c|c|c|c|c|c|}
\hline & Factor 1 & Factor 2 & Factor 3 & Factor 4 & Factor 5 & Factor 6 \\
\hline Stepparent Role & $.62 * *$ & $.72 * *$ & $.82 * *$ & $.60 * *$ & $.75 * *$ & $.45^{* *}$ \\
\hline \multicolumn{7}{|l|}{ Strain Index } \\
\hline Factor 1 & & $.27 * *$ & $.52 * *$ & $.19^{*}$ & $.31 * *$ & .02 \\
\hline Factor 2 & & & $.50 * *$ & $.23 *$ & $.55^{* *}$ & $.32 * *$ \\
\hline Factor 3 & & & & $.43 * *$ & $.55^{* *}$ & .17 \\
\hline Factor 4 & & & & & $.34 * *$ & $.23^{* *}$ \\
\hline Factor 5 & & & & & & $.30 * *$ \\
\hline
\end{tabular}

$* p<.05 . * * p<.01$.

Table 3

Correlations Matrix between the Spanish Version of the Stepparent Role Strain Index and the Stepparent Role Clarity Inventory Stepparent Role Clarity Inventory

Stepparent Role Strain Index
Role Ambiguity (Factor 1)
Role Overload (Factor 2)
Displacement in the Paternal-Filial Subsystem (Factor 3)
Affective Ambivalence (Factor 4)
Normative Discordance (Factor 5)
Ex-Spouse's Interference (Factor 6)

$-.477 * *$

$-.358 * *$

$-.237 *$

$-.485^{* *}$

$-.340 * *$

$-.304 * *$

$-.143$

$* p<.05 . * * p<.01$. 
With regard to stepparents' difficulties in the performance of their role, we would like to underline the contribution of our work to the study and measurement of this variable. Not only has a pioneer instrument in the study of stepparent role strain been adapted, but also this measure (role strain) has been complemented with a measure from another inventory (role clarity), allowing the analysis of the relation between these two variables. The 26-item version of the Stepparent Role Strain Index used obtained a high degree of internal consistency, the percentage of variance accounted for by the first factor of the unrotated matrix is satisfactory, and the values of the Cronbach's alphas and the IFFS of the six factors are all optimal. Moreover, the items belonging to each factor have similar contents, so it can be stated that the six dimensions adequately represent various aspects related to stepparents' experience of distress as a result of the behaviors they should perform within the family setting.

With regard to the sample size that participated in this work and the generalization of the results, we would like to note some aspects. Firstly, the number of stepparents who participated in the diverse investigations from the USA, where most of the publications of family structures has been carried out, does not usually exceed 50 subjects per work. This reflects the difficulty of obtaining a large sample of stepparents. Secondly, it was difficult to decide whether or not the sample used in this work is representative because the Spanish population census does not specify how many stepparents there are in our country. Although the percentage of second marriages of men and women or the proportion of people who marry, taking into account their civil status (single or divorced), is commonly provided as a number, it must be remembered that these data are not reliable indicators of the number of reconstructed families or of the number of stepparents who live in a reconstructed family, because these data do not specify whether these individuals are parents.

In contrast, the diversity of the sociodemographic characteristics of stepparents who took part in this study is noteworthy. Regarding the participants' sex, a similar number of stepfathers and stepmothers was obtained, which is infrequent in investigations in which the predominance of men is clear. Likewise, an effort was made to balance the stepparents' age range (between 31 and 51 years), as well as their duration in their couple relationship (between 1 and more than 10 years). We wanted to collect a sample that represented the great variability in this kind of families concerning family structure, simple and complex reconstructed families, the time the stepparents had been living with their stepchildren, and the stepchildren's age, etc.

We therefore believe that the 116 participants in this work comprise an acceptable number from which to extract initial information about the situation of some reconstructed families in Spain, through the subjective perception of one of the members. This is a starting point to continue with a line of research that is still incipient in our country.
As mentioned above, stepparents have special relevance in reconstructed families, as there are many works that have indicated that their integration is one of the most complex but necessary aspects to guarantee both stability and individual, marital, and family adjustment (Bray et al., 1994). However, the difficulties these family members commonly experience when undertaking family roles could prevent their integration within the family circle and lead to the dissolution of the family. It is therefore necessary for future research to focus on the effect of role strain on stepparents' health or well-being (Espinar, Carrasco, \& Hernández, 2007) so that prevention and intervention strategies can be designed to help them to cope adequately with the difficulties they face when performing their family roles.

\section{References}

Alberdi, I. (1999). La nueva familia española. Barcelona: Taurus. Bernstein, A.C. (2000). Remarriage. Redesigning couplehood. In P. Papp (Ed.), Couples on the fault line (pp. 284-311). NY: Guilford Press.

Bray, J.H., Berger, S.H., \& Boethel, C.L. (1994). Role integration and marital adjustment in stepfather families. In K. Pasley \& M. Ihinger-Tallman (Eds.), Stepparenting: Issues in theory, research and practice (pp. 69-86). Westport, CT: Greenwood.

Bumpass, L., Martin, T.C., \& Sweet, J.A. (1991). The impact of family background and early marital factors on marital disruption. Journal of Family Issues, 12, 22-42.

Campo del, S., \& Rodríguez-Brioso, M.M. (2002). La gran transformación de la familia española durante la segunda mitad del siglo XX. REIS, 100, 103-165.

Espinar, I., Carrasco, M.J., \& Hernández, M.J. (2008). Stepparent role strain and psychological distress in a Spanish sample. Manuscript submitted for publication.

Fine, M.A., Coleman, M., \& Ganong, L.H. (1998). Consistency in perceptions of the step-parent role among step-parents, parents and stepchildren. Journal of Social and Personal Relationships, 15, 810-828.

Fine, M.A., \& Schwebel, A.I. (1991). Stepparent stress: A cognitive perspective. Journal of Divorce and Remarriage, 17, 1-15.

Flaquer, L. (1999). La familia en la sociedad del siglo XXI. Barcelona: Fundació Rafael Campalans.

Fleming, J.S. (1985). An index of fit for factor scales. Educational and Psychological Measurement, 45, 725-728.

Ganong, L.H., \& Coleman, M. (1983). Stepparent: A pejorative term? Psychological Reports, 52, 919-922.

Glick, P.C. (1989). Remarried families, stepfamilies and stepchildren: A brief demographic profile. Family Relations, 38, 24-27.

Goode, W.J. (1960). A theory of role strain. American Sociological Review, 25, 483-496.

Gorell-Barnes, G., Thompson, P., \& Burchardt, N. (1997). Growing up in stepfamilies. Oxford, UK: Clarendon.

Iglesias de Ussel, J. (1994). La nupcialidad. In M. Juárez (Dir.), $V$ Informe Sociológico sobre la situación social en España (pp. 433-445). Madrid: Fundación FOESSA. 
Iglesias de Ussel, J. (1998). La familia española en el contexto europeo. In M.J. Rodrigo \& J. Palacios (Coords.), Familia y desarrollo humano (pp. 91-114). Madrid: Alianza Editorial.

Ihinger-Tallman, M., \& Pasley, K. (1987). Remarriage. Newbury Park, CA: Sage.

Instituto Nacional de Estadística (2001). Anuario estadístico. Retrieved at http://www.ine.es/ (October, 2005)

Kim, J., \& Mueller, C.W. (1994). Factor analysis. Statistical methods and practical issues. In M.S. Lewis-Beck (Ed.), Factor analysis and related techniques (pp. 75-155). London: Sage.

Lawton, J.M., \& Sanders, M.R. (1994). Designing effective behavioral family interventions for stepfamilies. Clinical Psychology Review, 14, 463-496.

McGoldrick, M., \& Carter, B. (1999). Remarried families. In B. Carter \& M. McGoldrick (Eds.), The expanded family life cycle. Individual, family and social perspectives (pp. 417-435). Boston, MA: Allyn \& Bacon.

Menéndez, S. (2001). La diversidad familiar en España. Un análisis de su evolución reciente y su aceptación. Apuntes de Psicología, 19, 367-386.
National Center for Health Statistics (1994). Monthly vital statistics. Washington, DC: U.S. Department of Health and Human Services, Public Health Service.

Orleans, M., Palisi, B.J., \& Caddell, D. (1989). Marriage adjustment and satisfaction of stepfathers: Their feelings and perceptions of decision making and stepchildren relations. Family Relations, 38, 371-377.

Pearlin, L.I. (1983). Role strains and personal stress. In H.B. Kaplan (Ed.), Psychosocial stress. Trends in theory and research (pp. 3-32). NY: Academic Press.

Visher, E.B., \& Visher, J.S. (1983). Stepparenting: Blending families' stress and the family. In C. Figley (Ed.), Stress and the family, 1 (pp. 133-146). NY: Brunner/Mazel.

Whitsett, D., \& Land, H. (1992). The development of a role strain index for stepparents. Families in Society: The Journal of Contemporary Human Services, 14-2.

Received January, 15, 2007 Review received September, 4, 2007 Accepted September, 19, 2007 